\title{
Trend Analysis in Ecological Status and Macrophytic Characterization of Watercourses: Case of the Semois-Chiers Basin, Belgium Wallonia
}

\author{
Sossey-Alaoui Khadija, Rosillon Francis, Tychon Bernard \\ Department of Environmental Sciences and Management (DSGE), University of Liege, Arlon, Belgium \\ Email: ksossey@ulg.ac.be, f.rosillon@ulg.ac.be, Bernard.Tychon@ulg.ac.be
}

Received 11 June 2015; accepted 30 August 2015; published 4 September 2015

Copyright (C) 2015 by authors and Scientific Research Publishing Inc.

This work is licensed under the Creative Commons Attribution International License (CC BY). http://creativecommons.org/licenses/by/4.0/

(c) (i) Open Access

\begin{abstract}
In order to analyze the distribution and evolution of the aquatic vegetation and ecological status of the Semois-Chiers basin (Semois sub-basin and Chiers sub-basin), macrophyte surveys were conducted at 48 sites in 2007 and 2013. Environmental parameters were also measured in order to characterize the waterbodies in terms of physico-chemical properties and anthropogenic pressure. The two-way clustering and indicator value (INDVAL) methods were used to assess groups of sites according to their macrophytic composition and species communities. The results showed a clear difference between streams in the Lorraine area (calcareous watercourses) and in the Ardennes (siliceous). Within each natural region, those with natural vegetation of high ecological status were separated from those dominated by resistant species. The Macrophytical Biological Index for Rivers (IBMR) was calculated for the sites visited in 2010 and 2013 and the results show a trend towards an increase of IBMR values of polluted sites. For the latter, the Wilcoxon test was performed to assess the significance of the difference in quality between 2010 and 2013 . This showed a statistically significant difference $(p$-value $=0.035)$. Our results showed similarities with previous data, as well as some differences. The differences observed might indicate a gradual change in the composition of the vegetation in the study area, which was caused by changes in environmental conditions. They could also reflect a lack of information about the ecology of certain groups of plants, mainly bryophytes and macroalgae that were not considered in previous studies. Despite the measures implemented under the EU's Water Framework Directive (WFD), the current vegetation of the Semois river differs little from that observed in 1996. The headwaters of a Semois river, described in previous studies as polytrophic and devoid of vegetation, show a slight improvement, with the appearance of macrophytic species. In some parts of the Chiers sub-basin, however, resistant species observed in 1999 persist.
\end{abstract}




\section{Keywords}

\section{Macrophytes, Semois-Chiers Basin, WFD, IBMR, Ecological Quality}

\section{Introduction}

Under the European Union's Water Framework Directive (WFD), the ecological status of a water body is evaluated on the basis of three main factors: biology, physical chemistry and hydromorphology. Macrophytes are an essential element in the functioning of aquatic ecosystems and are widely used in WFD work to assess ecological quality. In the Semois-Chiers basin, however, information on aquatic macrophytes is limited, apart from that in the work reported by [1]-[22]. Results from earlier studies on watercourses in this area were revised and updated by Thoen et al. [23] in a study conducted between 1993 and 1994.

Initiated in 1993 and focusing partly on a diachronic study of aquatic macrophytes as bio-indicators of water quality evolution in the Semois-Chiers basin, Thoen et al. [23] conducted an environmental study of the Semois river from its source to its confluence with the Meuse. The study brought together a great amount of new data on aquatic pond plants. Many species have since been reported for the first (or second) time in the Semois-Chiers basin. Thoen et al. [23] showed that there was a longitudinal succession of species along the Semois river and that this succession was determined by eco-chemical factors. They described macrophytic groups over a distance of $200 \mathrm{~km}$ based on an analysis of 218 botanical records. Although this study was important, it focused only on the main course of the Semois, not its tributaries, and only on the phanerogam group of plants.

In work carried out by Symoens [24], Dethioux [25] and Sossey-Alaoui [26], stream vegetation was defined in relation to physical descriptors and limited information was provided on the impact of human activities on ecosystems. Studies were also conducted on vascular plants and some information was provided on bryophytes and macroalgae. In these studies, the reference conditions were not specified and the communities studied included both sensitive and resistant species.

Despite these studies, the Semois-Chiers area remains under-surveyed. In terms of the regional distribution of many plant species, significant gaps remain and there is a need to update information in the light of recent changes in aquatic and semi-aquatic flora and of the results of WFD surveys. The gaps have arisen mainly because the aquatic vegetation of the area is difficult to study and often requires specialized equipment rarely used by botanists (high boots, canoes, rope with a grappling hook, and a curved-tooth trident with a telescopic arm).

Within the context of the WFD's River Basin Management Plan, a measurement programme and monitoring network have been set up for each watershed. The Semois-Chiers waterbodies are covered by the Walloon network for monitoring surface water status. Between 2007 and 2013, this network undertook several macrophytic surveys of waterbodies [27]. The reference macrophytic communities were waterbodies classified by the Walloon Government as being areas showing little or no human impact [28].

In order to improve water quality, and to work within the framework of the River Basin Management Plan, the Walloon Government has supported the construction and expansion of wastewater treatment plants. Between 2000 and 2013, 29 such plants, with a capacity of 117,025PE, were built in the Semois-Chiers basin.

In our study, we sought to analyze trends in the Macrophyte Biological Index for Rivers (IBMR) values and macrophytic community characteristics by comparing previous results with those produced in 2013 within the context of the WFD. The specific objectives of the study were to: i) analyze the aquatic vegetation at 48 sites on various waterbodies in the Semois-Chiers basin; ii) define the characteristics of the macrophytic communities at these sites and identify their eco-chemical indicators; and iii) analyze trends in the IBMR values and macrophytic community in order to identify any changes in the status of these sites resulting from measures implemented under the WFD.

\section{Materials and Methods}

\section{Study Area Sites}

Our study focuses on 48 sites along various waterbodies in the Semois-Chiers basin, which is part of the Meuse river basin and covers an area of $1759.34 \mathrm{~km}^{2}$, with the major rivers being the Chiers, Rulles, Semois and Vierre. 
The area comprises two distinct geological units: the Ardennes in the northern part of the basin and Lorraine in the southern part (Figure 1). The Ardennes area consists of schists, sandstone and quartzophyllade and is characterized by forests composed of deciduous and coniferous trees [27]. The Lorraine area consists of alternating impermeable (marl and clay) and permeable (conglomerates, sandstones, limestone and calcareous sandstones) ground. The alternating hard and soft layers of these deposits were originally eroded in formations called "cuestas". The Lorraine area is suitable for agriculture, but the tops and slopes of the cuestas are covered by forest.

The sites surveyed were mostly part of the monitoring network of Walloon surface waters. They represent various geological situations and physicochemical and anthropogenic pressures of the area. Some sites analyzed in 1999 [26] were revisited in 2013. Figure 1 shows the distribution of the 48 sites analyzed in the SemoisChiers basin. The sampling methodology was carried out using the IBMR protocol [29]. The length of the studied water sections was $100 \mathrm{~m}$. The estimation of coverage is carried out and sub-divided into five classes of abundance (class 1 : $<0.1 \%$, class 2 : from $0.1 \%-1 \%$, class 3 : from $1 \%-10 \%$, class 4 : from $10 \%-50 \%$, class 5 : from $50 \%-100 \%$ ). The estimation of plant cover was made for riverbed and margins as a whole.

The submerged macrophytes were surveyed twice during the main growing periods in 2007-2008, 2008-2009 and 2012-2013.

The physico-chemical parameters measured at 25 out of the 48 sites were: complete alcalimetric title (CTA) $\left({ }^{\circ} \mathrm{F}\right)$; conductivity $(\mu \mathrm{S} / \mathrm{cm})($ microSiemens/cm); calcium $(\mathrm{mg} / \mathrm{l})$; orthophosphate $(\mathrm{mgP} / \mathrm{l})$; nitrite $(\mathrm{mgN} / \mathrm{l})$; ammonium (mgN/l); and $\mathrm{pH}$. The measurements were made six times a year. The environmental parameters used (artificial environments, agricultural land, forests and semi-natural habitats) are related to the percentage in the basin.

For the vegetative data analysis, we used two-way clustering [30] to investigate stream groups in terms of their vegetation and indicator value (INDVAL) [31] in order to identify taxa characteristics of the floristic types that were present.

The two-way clustering method simultaneously assigns sites and species groups by performing two separate classification analyses, one on a matrix looking at groups within rows (sites) and the second on the transposed matrix looking at groups within columns (taxa) (Figure 2). The figure shows the two dendrograms resulting from the first group of lines (sites) and the second group of columns (species) of the matrix and the taxa abundance [27]. The INDVAL technique allows taxa characteristic of groups defined by the two-way clustering method to be identified by calculating the abundance, relative frequency and INDVAL of each taxon in each group [31]. In order to be considered as a characteristic or indicator group, a taxon must have an indicator species value greater than $25 \%$.

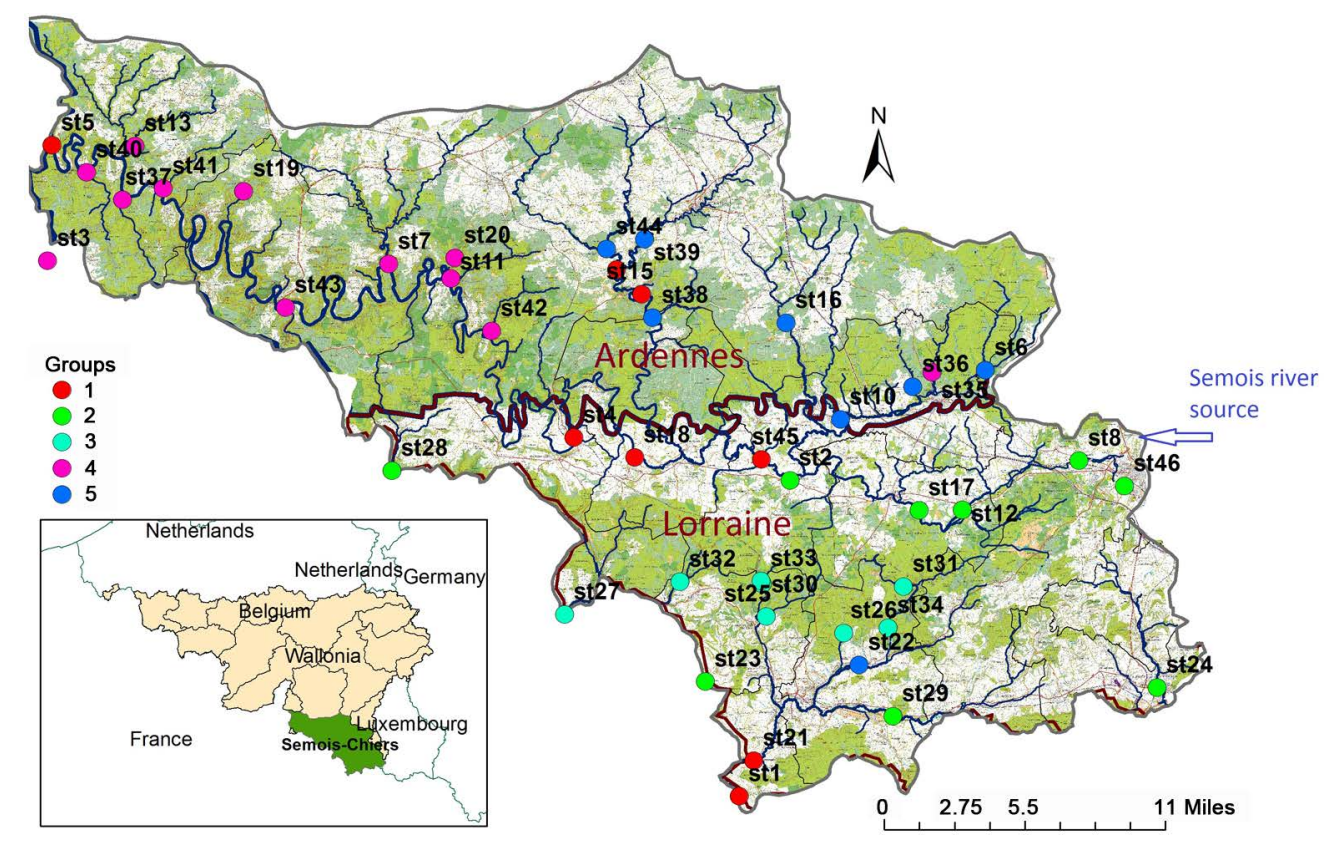

Figure 1. Distribution of the studied sites in five groups according to the results of two-way clustering analysis. Sites codes and reference in electronic Appendix 1). 
Principal component analysis (PCA) was performed to characterize the groups in terms of the physico-chemical parameters of their environment.

The IBMR [32] was calculated for each site and a box-whisker plot test was used to characterize the groups in terms of their trophic state.

\section{Results and Discussion}

\subsection{Analysis of the Vegetation Distribution in the Semois-Chiers Basin}

The two-way clustering method was used to investigate groups of sites determined by their emerging macrophytic composition and species communities (Figure 2). Within the five groups defined, the results showed a

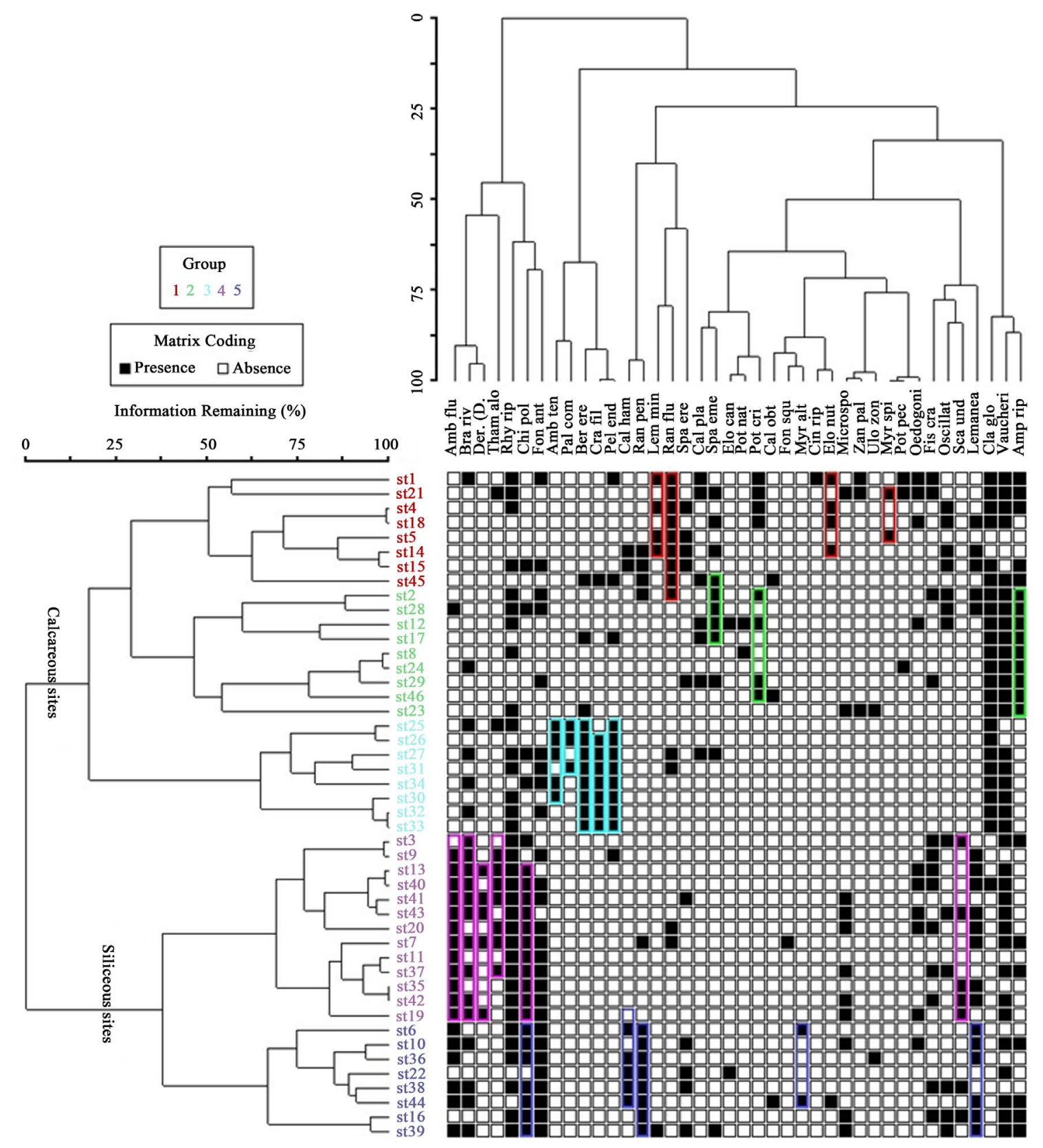

Figure 2. Results of two-way clustering analysis applied to the vegetation matrix of Semois-Chiers (Species abbreviations and full name are in electronic Appendix 2. Sites codes and reference in electronic Appendix 1). 


\section{S.-A. Khadija et al.}

clear difference between the Lorraine (calcareous watercourses) groups (2 and 3) and the Ardennes ones (siliceous) (4 and 5). Within each geological context, those with natural vegetation of high ecological quality were separated from those dominated by resistant species. Rivers, however, in both the Lorraine and the Ardennes, fell into Group 1.

PCA was performed to characterize the groups in terms of their physico-chemical and environmental parameters (Figure 3).

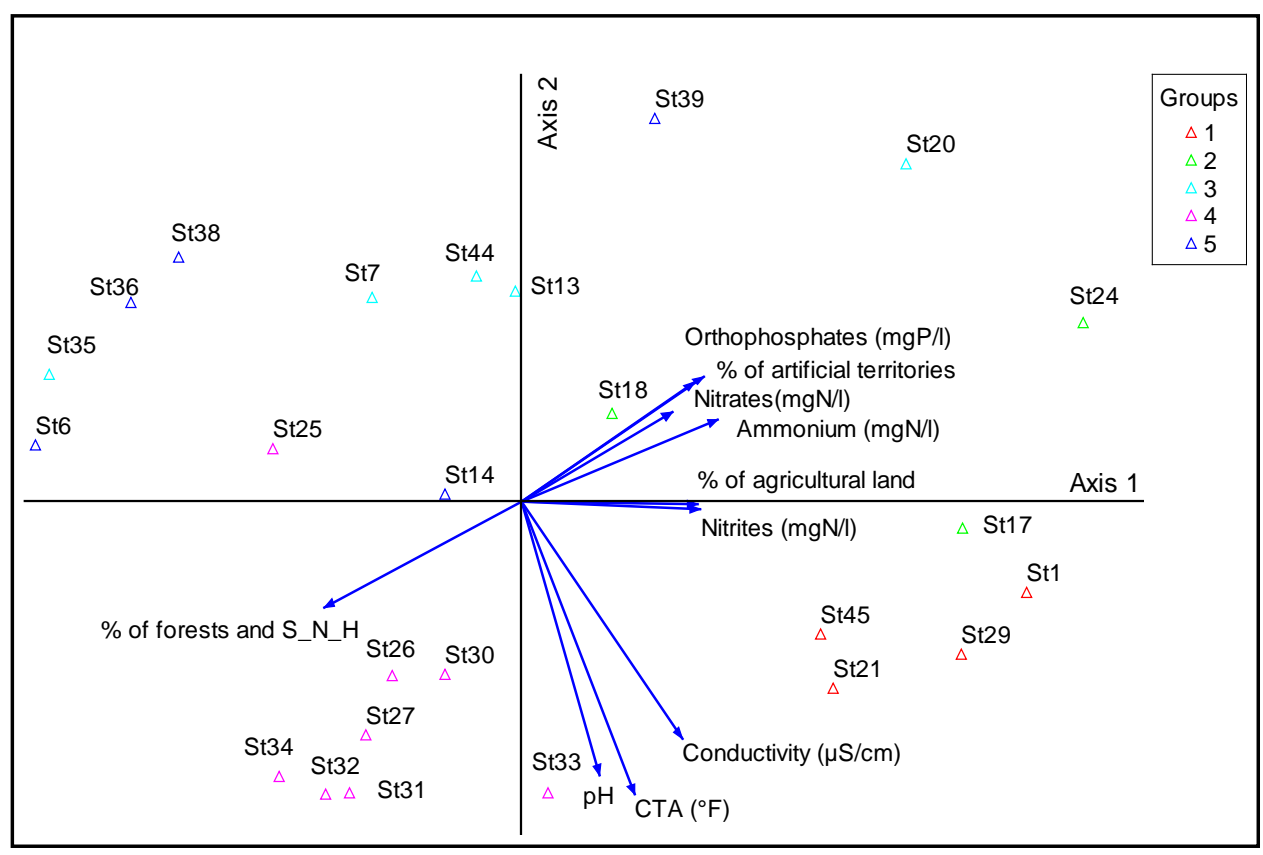

(a)

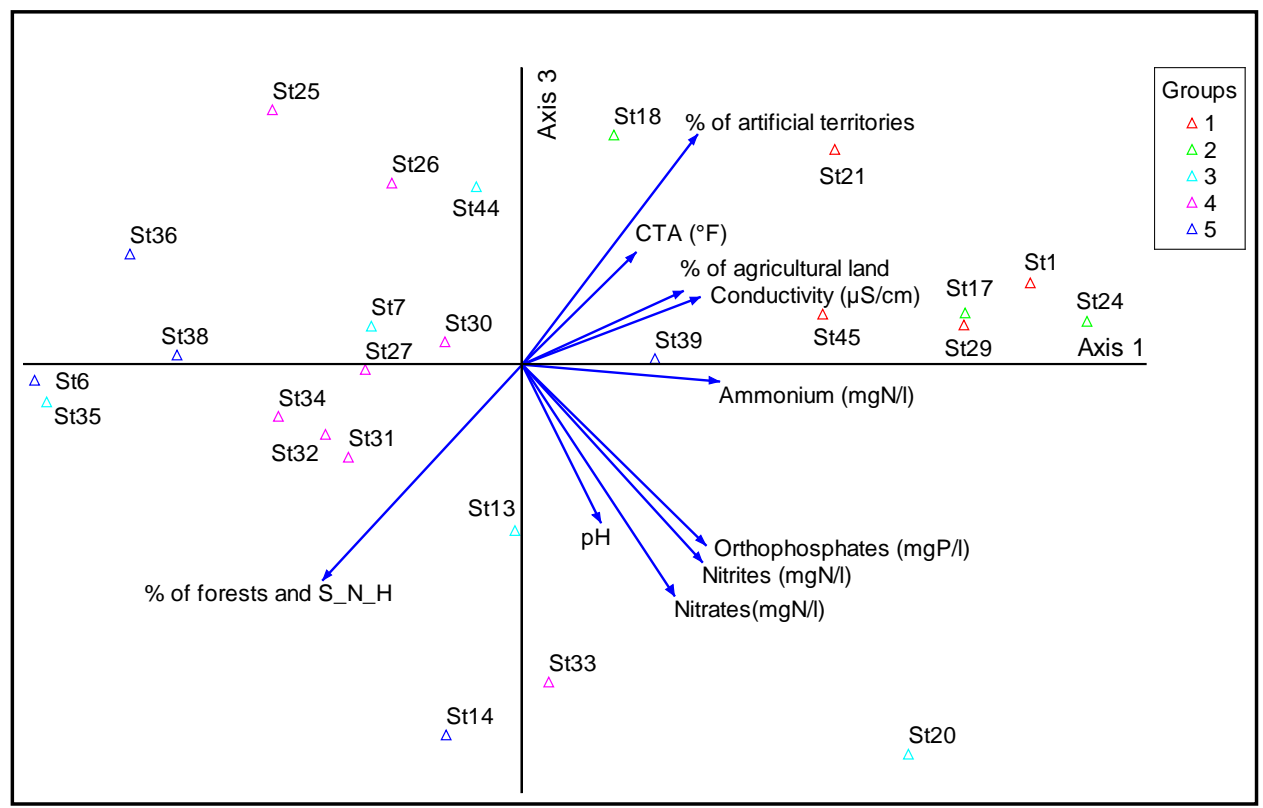

(b)

Figure 3. Results of the principal component analysis applied to the physico-chemical data of 25 out of the 48 sites studied. The sites are colour-coded in order to differentiate the five groups of sites determined by two-way clustering analysis. (a) Axis 1 and 2; (b) Axis 1 and 3. CTA = complete alcalimetric title ( $\left.{ }^{\circ} \mathrm{F}\right)$; \% of Forest and S-N-E: \% of Forest and Semi-Natural Environment. 
Lowland rivers (calcareous and siliceous watercourses) (Group 1)

Group 1 was characterized by sites on medium-sized streams and rivers in the Lorraine and by sites on large rivers in the Ardennes. The watercourse size was determined according to the typology used in Wallonia [33].

Figure 3 shows that these sites were characterized by high alkalinity and conductivity and a high concentration of nitrates. They also had a eutrophic character and eutrophication indicator species, including Ranunculus fluitans, Myriophyllum spicatum and Lemna minor (Figure 2), as well as low IBMR scores (Figure 4).

Calcareous streams (Lorraine area) (Groups 2 and 3 )

Group 2 stream sites, dominated by species indicative of eutrophication, predominated in agricultural areas and in the few forests in the watershed areas (Figure 3). These sites had high values in the various physicochemical parameters considered in our study (orthophosphate [mgP/l]; nitrite [mgN/l] and ammonium [mgN/l] (Figure 3). They were along the upper Semois and Vire (the main tributary of the Ton in the Chiers sub-basin) located on plains, drained farmland and urban or industrial areas. Species characteristic of this group were Leptodictyum riparium and Potamogeton crispus (Figure 2).

In contrast, Group 3 was characterized by low agricultural pressure and a strong dominance of forests in the watershed areas (Figure 3). It was also characterized by a macrophytic community dominated by species with a natural calcareous character of high biological value, including Hygroamblystegium tenax, Berula erecta, Cratoneuron filicinum and Pellia endiviifolia (Figure 2), as well as high IBMR scores (Figure 4).

Siliceous streams (Ardennes area) (Groups 4 and 5 )

The Group 4 sites were characterized by low agricultural pressure and a strong dominance of forests. Some sites were on tributaries on the right bank of the Semois river in the Ardennes, where the lithological deposits are quartzophyllades, phyllites, sandstones and psammites and the predominant land use is forestry (Figure 3). In terms of abundance and frequency, the main indicator species were Hygroamblystegium fluviatile, Chiloscyphus polyanthus, Brachythecium rivulare, Dermatocarpon weberi, Thamnobryum alopecurum and Scapania undulata. These species have a very high indicator value and are therefore indicator species of high ecological status.

In contrast, the Group 5 sites were in areas with more agriculture and fewer forests (Figure 3) and were characterized by taxa that tended to be less sensitive. This could be explained by these sites being on the Ardennes plateau, which was dominated by grasslands. This situation was also reflected in the IBMR results (Figure 4), where the trophic levels were average for most of these Group 5 sites.

In these disturbed sites small amounts of some species characteristic of the reference streams persisted, especially Chiloscyphus polyanthus, Hygroamblystegium fluvialile Platyhypnidium riparioides and Brachythecium

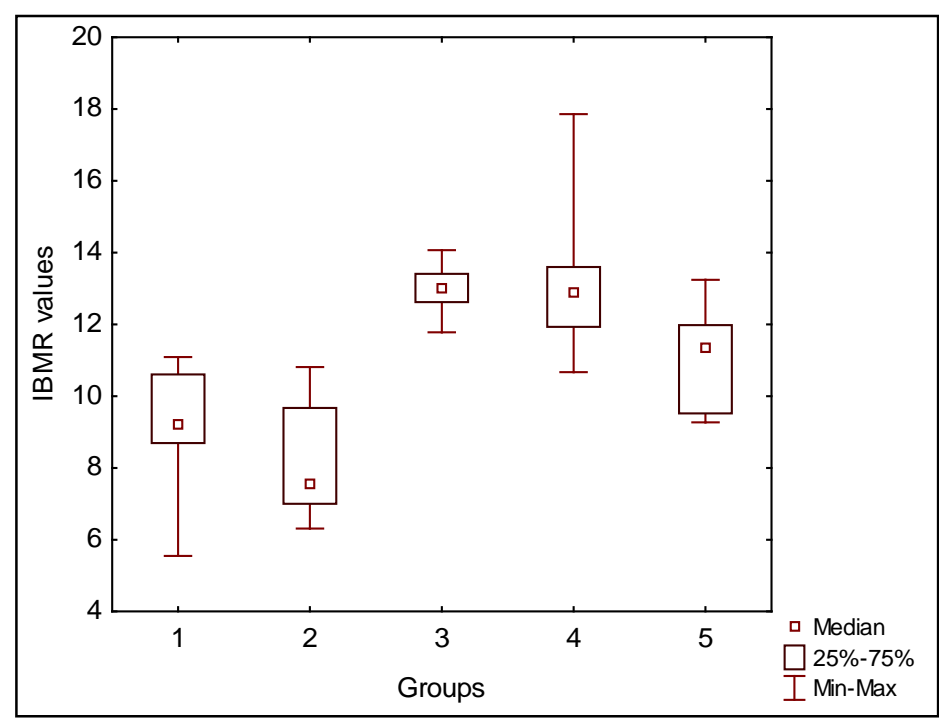

Figure 4. IBMR values of the groups of sites defined by two-way clustering analysis. The box plot shows the central tendency of the variable in terms of median values (represented by the smallest box plot). The dispersion (variability) of the variable values is shown by quartiles (25th and 75th percentiles, larger box plot) and the minimum and maximum values of the variable ("whiskers" plot). 
rivulare. Others had disappeared and had been replaced by less sensitive species (e.g., higher plants, such as Callitriche hamulata, Ranunculus penicillatus and, to a lesser extent, Elodea nuttallii, Lemna minor, Callitriche platycarpa and Callitriche obtusangula, as well as macroalgae including Microspora sp. and Oedogonium sp. The quality difference between the sites of the two groups was also reflected in the difference of nitrate concentration (Figure 3).

\subsection{Comparison with Previous Data}

\subsubsection{Analysis of Trends from 2010 to 2013}

Eleven sites in Groups 1, 2 and 5 characterized by resistant species were subjected to analyses, the first conducted in 2010 and the second in 2013. The IBMR results from these two analyses are given in Table 1, which shows a trend towards improved ecological quality. The Wilcoxon test was performed to assess the significance of the difference in quality between the two years. This produced a statistically significant difference (p-value of $<0.05)$.

This trend could be related to an improvement in water quality, but also to the difference in climatic conditions (hydrology, temperature) not considered in this study between the two years.

\subsubsection{Comparison of Results with Previous Data}

In the Semois sub-basin, our comparative work focused mainly on phanerogams and on the main Semois river. Thoen et al. [23], who identified a set of macrophytic groups related to physico-chemical quality, focused only on the main Semois river. There are no results, therefore, for the Semois tributaries. Also, by focusing only on phanerogams, this meant excluding bryophytes and macroalgae, which had not been considered in previous studies.

The IBMR results from these two analyses are given in Table 2, which shows a trend of increasing IBMR values.

The first kilometer after the source (St 46), a little downstream from the largest town (Arlon) in the basin, was described in 1982 by the authors and others [34] as polytrophic and lacking vegetation as a result of pollution.

The presence of species in this section today, although they are indicators of pollution (Leptodictyum riparium and Cladophora glomerata), shows a tendency towards improvement in water quality. This could be the result of pollution control measures implemented by the Walloon Government under the WFD.

In an effort to improve sewage management in the Semois-Chiers basin, the Walloon Government is supporting the construction and expansion of wastewater treatment plants. Between 2000 and 2013, 29 such plants with a capacity of 117,025 PE were built in the basin. This has led to an improvement in physico-chemical quality,

Table 1. Ecological quality difference between 2010 and 2013 at 11 streams of Semois-Chiers basin.

\begin{tabular}{cccc}
\hline IBMR Values/Sites & $\mathbf{2 0 1 0}$ & $\mathbf{2 0 1 3}$ & Group 1 \\
\hline St1 & 8.49 & 10.48 & 9.77 \\
St15 & 10.25 & 6.75 & Group 2 \\
St24 & 6.31 & 10.08 & \\
St2 & 9.89 & 12.29 & 9.68 \\
St17 & 8 & 7.57 & Group 5 \\
St28 & 9.67 & 12.76 & 12.64 \\
St29 & 7.35 & 11.98 & 11.52 \\
St36 & 12.25 & 11.33 \\
St38 & 10.45 & 11.79 & Wilcoxon test $(\boldsymbol{p}=\mathbf{0 . 0 3 4 )}$ \\
\hline
\end{tabular}


Table 2. Comparison of Semois river results with previous data. Thoen et al. [23] results vs. 2013 results.

\begin{tabular}{|c|c|c|c|c|c|c|c|c|c|c|c|c|}
\hline \multirow[t]{2}{*}{ Sites/Parameters } & \multicolumn{2}{|c|}{ St46 } & \multicolumn{2}{|c|}{ St8 } & \multicolumn{2}{|c|}{ St17 } & \multicolumn{2}{|c|}{ St2 } & \multicolumn{2}{|c|}{ St4 } & \multicolumn{2}{|c|}{ St5 } \\
\hline & 1996 & 2013 & 1996 & 2013 & 1996 & 2013 & 1996 & 2013 & 1996 & 2013 & 1996 & 2013 \\
\hline \multicolumn{13}{|c|}{ Physico-chimical parameters } \\
\hline Orthophosphate (mgP/l) & 0.75 & 0.14 & 0.21 & $\mathrm{x}$ & 0.15 & 0.14 & 0.055 & 0.07 & 0.044 & 0.04 & 0.025 & 0.03 \\
\hline Nitrate (mgN/l) & & & 3.1 & $\mathrm{x}$ & 2.02 & 2.72 & 1.64 & 1.84 & 1.64 & 2.17 & 1.8 & 1.92 \\
\hline Ammonium (mgN/l) & 0.80 & 0.22 & 0.97 & $\mathrm{x}$ & 0.49 & 0.22 & 0.115 & 0.11 & 0.088 & 0.019 & 0.042 & 0.019 \\
\hline \multicolumn{13}{|c|}{ IBMR } \\
\hline \multirow[t]{2}{*}{ IBMR value } & & 8.58 & 9.13 & 11 & 5.24 & 9.78 & 8.15 & 8.88 & 8.53 & 9.16 & 8.26 & 9.14 \\
\hline & & & \multicolumn{10}{|c|}{ IBMR 1996 vs. IBMR 2013 (Wilcoxon test $(p=0.043115)$ ) } \\
\hline
\end{tabular}

NB. IBMR 1996 and 2013 were calculated without Macroalgae and bryophytes taxas.

mainly in terms of nitrogen and phosphorus. In the Semois river at Arlon (St46), concentrations of $\mathrm{NH}_{4}^{+}$and $\mathrm{PO}_{4}^{3-}$ fell from 0.80 and 0.75 in 1996 to 0.22 and $0.14 \mathrm{mg} / \mathrm{l}$ in 2013, respectively.

From St8 to the confluence with the Rulle (the first major tributary of the Semois, before St2), most species reported in 1996 are still there, including Potamogeton natans, Sparganium emersum and Elodea nuttallii.

The sandy-marly substrate in this part of the river is the main site of phosphorus trapping, especially under toxic conditions, but it can also be a source of phosphorus salt in the overlying water under certain conditions of $\mathrm{pH}$ and redox potential that affect phosphorus mobility [35] [36]. The release of phosphorus therefore plays a significant role in the development of macrophytes and might increase the trophic levels of the river in spite of pollution control efforts.

In their study, Thoen et al. [23] explained the presence of these resistant species by reshaping the longitudinal (and transverse) section of the upper Semois river, changing the natural environmental conditions. These conditions have favored a few opportunist and pollution-tolerant species, particularly Sparganium emersum.

In this first transect of the Semois river, the mineral richness of the waters combined with morphological pressures and alterations have radically changed the composition of the plant communities there. GlycerioSparganion species (especially Glyceria plicata in eutrophic waters rich in calcium) were present in the river headwater area before the environmental disturbances, but this is no longer the case. These species are still present, however, in the Lorraine area in smaller Semois watercourses with a loose alluvial substrate [37].

Among the species that have regressed or are missing in the upper Semois is Potamogeton pectinatus. The decline of this species, considered to be an indicator species of unusually rich waters (polytrophic waters, indicating eutrophication of the river; e.g., [38]-[41]) can be taken as a sign of slight improvement in the water quality here.

In mid- and lower Semois river, most species mentioned in 1996 are still there. In these stretches the tributaries vary in importance, flow level and water quality. Most tributaries reach the Semois from the northern side of the catchment area, on the right bank, and their water quality is good.

In this part, and despite crossing much poorer primary geological substrates, the river retains its original limestone-rich water. Its vegetation, dominated by Ranunculus fluitans, only partially reflects annual changes in habitat.

Our comparative analysis of the tributaries of the Semois was conducted with reference to the work done by Dethioux [37]. He described the ground waters from Early Devonian slaty sandstone, slaty quartz or phillite slate formations, with $\mathrm{N}\left(\mathrm{NO}_{3}^{-}\right)$levels of $1-2 \mathrm{mg} / \mathrm{l}$ and a $\mathrm{P}\left(\mathrm{PO}_{4}^{3-}\right)$ content equal to or lower than $0.01 \mathrm{mg} / \mathrm{l}$, similar to the Ardennes mesotrophic waters. The macrophytic community he reported as characteristic of these environments was dominated by bryophytes fixed to boulders (Chiloscyphus polyanthos, Pellia epiphylla and Amblystegium fluviatile), as well as rheophilic species such as Fontinalis antipyretica, Fontinalis squamosa and Rhynchostegium riparioides and higher plants such as Ranunculus penicillatus and Callitriche hamulata.

All the species Dethioux [37] mentioned were observed in our surveys, reflecting the persistence of the natural state in these environments. According to Dethioux [37], Lorraine streams with a water $\mathrm{pH}$ close to neutral or slightly alkaline, and with high conductivity and an important load of calcium bicarbonate, are characterized by 
species restricted to these conditions, such as bryophytic flora, including the moss Cratoneuron commutatum, which is involved in the genesis of travertine and tuff found in stream beds.

In some parts of the Chiers sub-basin, however, resistant species observed in 1999 [26] persist (e.g., Potamogeton crispus, Myriophyllum spicatum and Elodea nuttallii, in St29 and St21). This could be explained technically and is also apparent when looking at changes in physico-chemical parameters over short periods. Identifying trends requires working over longer periods. In addition, the water's ecological status is a synthetic and aggregated indicator. In order to improve it significantly, it would be necessary to implement a program of measures of the different types of constraints leading to the degradation, and to build in a sufficiently long response time of the ecosystem to these changes.

\section{Conclusions}

In order to investigate the floristic typology of the watercourses of the Semois-Chiers basin, a two-way clustering method was used. Five groups of watercourses were identified using this method.

The results of the Macrophyte Biological Index for Rivers (MBIR) calculated for the sites in the different groups corroborated the physico-chemical quality measured for each group. The trophic level was low in most of the Lorraine streams (upper part of the Semois river, the Vire [main tributary of the Ton] and the Messancy [tributary of the Chiers]), indicating a vegetation dominated by disturbance species. It was high in the Semois Ardennes tributaries and those of the right bank of the Ton (tributary of the Chiers sub-basin), which were all water bodies with natural vegetation.

Compared with previous data, our results showed similarities as well as some contradictions. The contradictions might be indicative of a gradual change in the composition of the vegetation in the study area, resulting from changes in environmental conditions. They could also reflect the lack of information on the ecology of certain groups of plants not considered in precious studies, especially bryophytes and macroalgae.

Despite the measures applied as part of the implementation of the WFD, the current vegetation of the Semois differs little from that observed in 1996. There is a slight improvement in some streams, such as the upstream section of the Semois, which was described in previous studies as polytrophic and devoid of vegetation, but now has some macrophytic species.

\section{Acknowledgments}

We thank the Walloon Public Service through various conventions by which we collect the data processed. The authors would also like to thank Galoux D. and Cherot F. (Departement de l'Etude du Milieu Naturel et Agricole) for their assistance and "ISSEP” (Scientific Institute of Public Service) for physicochemical analysis.

\section{References}

[1] Pire, L. (1864) Third Herborization of the Royal Botanical Society of Belgium. Bulletin of the Royal Botanical Society of Belgium, 3, 314-335.

[2] Crépin, F. (1881) Account of the XIX General Herborization of Royal Botanical Society of Belgium. Bulletin of the Royal Botanical Society of Belgium, 20, 128-142.

[3] Verhulst, A. (1923) Proceedings of the Herborization Carried out in the Valley of the Semois, 19, 20 and 21 June 1921. Bulletin of the Royal Botanical Society of Belgium, 55, 62-68.

[4] Lambinon, J. and De Sloover, J.L. (1965) Trip of 21 July 1965 to Rochehaut Poupehan and North of Vresse. Natura Mosana, 18, 93-95.

[5] Lambinon, J. (1966) Cotoneasler integerrimus and Saxifraga sponhemica between Chiny and Lacuisine. Bulletin of the Royal Botanical Society of Belgium, 99, 377.

[6] D’Ansembourg, V., De Zuttere, P., Louette, A., Matagne, G. and Parent G.H. (1967) Some Interesting Vascular Plants of Southern Ardennes and Jurassic District. Lejeunia N.S., 44,1-47.

[7] Delvosalle, L., Demaret, F., Lambinon, J. and Lawalrée, A. (1969) Rare Extinct or Risk of Extinction Plants in Belgium: The Loss of Native Flora. Ministry of Agriculture, Water and Forestry Administration, Department of Natural Reserves and Conservation of Nature Works, 4, $128 \mathrm{p}$.

[8] Tanghe, M. (1968) Forest Vegetation in the Valley of the Ardennes Semois. Part I: Ecological Groups. Bulletin of the Royal Institute of Natural Sciences of Belgium, 44, 1-55. 
[9] Tanghe, M. (1970) Forest Vegetation of the Ardennes Semois Valley. Part Two: Forest Associations Stational of the Slope. Bulletin of the Royal Botanical Society of Belgium, 46, 1-60.

[10] Dethioux, M. (1969) A Short Note Describing the Tintigny Seat. 218W. Vegetation Map of Belgium, 44 p.

[11] De Zuttere, P. (1969) Semois River Valley in Chiny. National Parks, 24, 17-19.

[12] Duvigneaud, J. (1972) Flora and Vegetation of an Ardennes Valley. Valley Semoy in Thilay and Hautes-Rivières (Department of Ardennes, France). Natura Mosana, 25, 50-71.

[13] De Zuttere, P. and Jaqemart, J. (avec la coll. de De Sloover) (1973) Excursion of 21 July, 1972 in the Natural Reserve of Bohan-Membre. Natura Mosana, 26, 43-45.

[14] Parent, G.H. (1973) Chorologic and Ecological Notes on the Flora of the Province of Luxembourg. Lejeunia N.S., 68, $1-88$.

[15] Rappe, A., Marlier, G., Boosten, G., Devillers, P., Everaerts, G.-H., Parent, G.-H., Symoens, J.-J. and Vanden Berghen, C. (1973) The Site of Conques. Belgium Naturalistes, 54, 396-400.

[16] Symoens, J.-J. and Vanden Berghen, C. (1974) The Association with Eleocharis soloniensis (Dubois) Harain Conques (Ste.-Cécile, Belgian Luxembourg). Bulletin of the Royal Botanical Society of Belgium, 107, 285-290.

[17] Noirfalise, A. and Dethioux, M. (1977) Synopsis of Aquatic Vegetation of Fresh Water in Belgium. Communication of Forest Ecology and Rural Centre (Gembloux) N.S., 14-25.

[18] Parent, G.H. and Thoen, D. (1982) Chorologic and Ecological Notes on the Flora of the Province of Luxembourg. Lejeunia N.S., 108, 1-41.

[19] Thoen, D. (1984) The Flora and Vegetation of the Bouillon Castle and Its Surrounding Area (Province of Luxembourg, Belgium). National Parks, 33, 39-50.

[20] Dethoux, M. and Noirfalise, A. (1985) Rheophile Groups with Aquatic Ranunculus in Middle and High Belgium. Tuexenia, 5, 31-39.

[21] Dethioux, M. (1989) Noteon Semois Vegetation. Tribune de l'eau, 42, 12-14.

[22] Saintenoy-Simon, J. (1994) Over the Ardennes Semois Some Recent Botanical Observation. Adoxa, 2, 7-12.

[23] Thoen, D., Roussel, L. and Nicolas, J. (1996) Studies of Vascular Aquatic Macrophytes Groups of Semois Related to the Overall Water and Environment Quality. Ecologie, 27, 223-232.

[24] Symoens, J.P. (1957) Running Waters of the Ardenne and Neighboring Areas: Environments and Their Algal Vegetation. Bulletin de la Société Royale de Botanique de Belgique, 89, 1-111.

[25] Dethioux, M. (1991) Watercourses of Wallonia: Physical and Floristic Characteristics_-Principles and Verduration Techniques. 141.

[26] Sossey-Alaoui, K. (1999) Contribution to the Assessment of Aquatic and Riparian Vegetation of the Ton Watershed in Relation to the Aquatic Environment Quality. Post-Graduate Diploma (DEA) in Environmental Sciences, Department of Science and Environmental Management, University of Liege (ex. FUL), 227 p.

[27] Sossey-Alaoui, K. and Rosillon, F. (2013) Macrophytic Distribution and Trophic State of Some Natural and Impacted Watercourses-Belgium Wallonia. International Journal of Water Sciences, 2, 1-11. http://dx.doi.org/10.5772/56609

[28] Galoux, D., Cherot, F., Rosillon, F. and Sossey-Alaoui, K. (2015). Contribution to the Macrophytic Typology of Belgian Reference Watercourses. Advances in Botany, 2015, Article ID: 651369.

[29] Afnor (2003) Qualité de l'eau Détermination de l’indice biologique macrophytique en rivière (IBMR). Association Française de Normalisation T90-395, 28.

[30] McCune, B. and Grace, J.B. (2002) PCORD Analysis of Ecological Communities. MJM Software Design, Gleneden Beach.

[31] Dufrene, M. and Legendre, P. (1997) Species Assemblages and Indicator Species: The Need for a Flexible Asymmetrical Approach. Ecological Monographs, 67, 345-366. http://dx.doi.org/10.2307/2963459

[32] Haury, J., Peltre, M.C., Tremolières, M., Barbe, J., Thiebaut, G., Berne, L., Daniel, H., Chatenet, P., Muller, S., Dutartre, A., Laplace Treyture, C., Cazaubon, A. and Lambert Servien, E. (2002) A Method Involving Macrophytes to Assess Water Trophy and Organic Pollution: The Macrophyte Biological Index for Rivers (IBMR) - Application to Different Types of Rivers and Pollutions. In: Montel, D.M.H., Eds., Proceedings of the 11th EWRS International Symposium on Aquatic Weeds, Moliets Et Maa, 2-6 September 2002, 247-250.

[33] Vanden Bossche, J.P. and Usseglio-Polatera, P. (2005) Characterization Ecological Status and Type-Specific Reference Conditions of Surface Water Bodies in Wallonia (Belgium) Using Biocenotic Metrics Based on Benthic Invertebrate Communities. Hydrobiologia, 551, 253-271. http://dx.doi.org/10.1007/s10750-005-4465-y

[34] Vander Borght, P. (1982) Physico-Chemical Study of Semois for a Quality Management. PhD Thesis, Fondation Universitaire Luxembourgeoise, Arlon, 264 p. 
[35] Bostrom, B. (1988) Relations between Chemistry, Microbial Biomass and Activity in Sediments of a Sewage-Polluted vs. a Nonpolluted Eutrophic Lake. Verhandlungen des Internationalen Verein Limnologie, 23, 451-459.

[36] Enell, M. and Löfgren, S. (1988) Phosphorus in Interstitial Water: Methods and Dynamics. Hydrobiologia, 170, 103132. http://dx.doi.org/10.1007/BF00024901

[37] Dethioux, M. (1980) Riparianglyceraies of Belgium. Natura Mosana, 33, 128-136.

[38] Wiegleb, G. (1983) Methodological Research on Plant Communities of Running Waters. In: Géhu, J.M., Ed., Aquatic Plants and Amphibians, Colloques Phytosociologiques, 10 Cramer, Vaduz, 68-83.

[39] Carbiener, R., Trémolières, M., Mercier, J.L. and Ortschieit, A. (1990) Aquatic Macrophytes Communities as Bioindicators of Eutrophication in Calcareous Oligosaprobe Stream Waters (Upper Rhine Plain, Alsace). Vegetatio, 86, 71-88. http://dx.doi.org/10.1007/BF00045135

[40] Haury, J. and Peltre, M.C. (1993) Advantages and Limitations of "Macrophytic Indexes” to Describe Mesology and Physico-Chemistry of Streams: Armoricains, Picardy and Lorraine Examples. Annales de Limnologie, 29, 239-253. http://dx.doi.org/10.1051/limn/1993020

[41] Grasmuck, N., Haury, J., Leglize, L. and Muller, S. (1995) Assessment of the Bio-Indicator Capacity of Aquatic Macrophytes Using Multivariate Analysis. Hydrobiologia, 300-301, 115-122. http://dx.doi.org/10.1007/BF00024453 
Electronic Appendix 1. Geographical situation of the sampling sites.

\begin{tabular}{|c|c|c|c|c|c|c|c|}
\hline No. & Watercourses & $\mathrm{X}$ & $\mathrm{Y}$ & No & Watercourses & $\mathrm{X}$ & $\mathrm{Y}$ \\
\hline St1 & Chiers & 229,409 & 22,214 & St31 & GrosRuis & 239,750 & 35,403 \\
\hline St2 & Semois & 232,601 & 42,060 & St32 & LaSoye & 225,677 & 35,684 \\
\hline St3 & Goutelle & 185,860 & 55,899 & St33 & Lahage & 230,792 & 35,757 \\
\hline St4 & Semois & 218,998 & 44,776 & St34 & Laclaireau & 238,786 & 32,794 \\
\hline St5 & Semois & 186,134 & 63,149 & St35 & Arlune & 241,552 & 48,885 \\
\hline St6 & Rulles & 244,912 & 49,000 & Sst36 & Anlier & 240,340 & 47,977 \\
\hline St7 & Aleines & 207,339 & 55,685 & Sst37 & Rebais & 190,569 & 59,730 \\
\hline \multirow[t]{2}{*}{ St8 } & Semois & 250,807 & 43,307 & St38 & Bronvirys & 223,943 & 52,315 \\
\hline & & & & St39 & Neuchateu & 223,430 & 57,230 \\
\hline St10 & Mandebras & 235,777 & 45,915 & St40 & Membre & 188,315 & 61,459 \\
\hline St11 & Aise & 211,257 & 54,782 & St41 & Gros Fays & 193,130 & 60,434 \\
\hline St12 & Semois & 243,458 & 40,207 & St42 & Antrogne & 213,817 & 51,464 \\
\hline St13 & RuAu Moulin & 191,366 & 63,114 & St43 & Manbe & 200,838 & 52,945 \\
\hline St14 & Vierre & 220,889 & 56,482 & St44 & Grandvoir & 221,048 & 56,634 \\
\hline St15 & Vierre & 221,682 & 55,335 & St45 & Breuvanne & 230,796 & 43,392 \\
\hline St16 & Mellier & 232,345 & 51,986 & St46 & Semois & 253,661 & 41,719 \\
\hline St17 & Semois & 240,750 & 40,204 & & & & \\
\hline St18 & Semois & 222,821 & 43,507 & & & & \\
\hline St19 & Liresse & 198,204 & 60,270 & & & & \\
\hline St20 & Muno & 211,494 & 56,057 & & & & \\
\hline St21 & Ton & 230,330 & 24,452 & & & & \\
\hline St22 & Ton & 236,943 & 30,469 & & & & \\
\hline St23 & Thonne & 227,285 & 29,412 & & & & \\
\hline St24 & Messancy & 255,725 & 29,033 & & & & \\
\hline St25 & Lanframba & 231,118 & 33,503 & & & & \\
\hline St26 & Rabais & 235,994 & 32,482 & & & & \\
\hline St27 & Marche & 218,404 & 33,636 & & & & \\
\hline St28 & Ru du Tremble & 207,553 & 42,680 & & & & \\
\hline St29 & Vire & 239,095 & 27,244 & & & & \\
\hline St30 & Chavratte & 230,849 & 35,581 & & & & \\
\hline
\end{tabular}


Electronic Appendix 2. Species abbreviations and full name.

AMBFLU: Hygroamblystegium fluviatile (Hedw.) Loeske AMBTEN: Hygroamblystegium tenax (Hedw.) Jenn. BERERE: Berula erecta (Huds.) Coville MYRALT: Myriophyllum alterniflorum DC. BRARIV: Brachythecium rivulare Schimp. CALHAM: Callitriche hamulata Kutz. ex Koch CALOBT: Callitriche obtusangula Le Gall PALUCOM: Palustriella commutata (Hedw.) Ochyra CALPLA: Callitriche platycarpa Kutz. CHIPOL: Chiloscyphus polyanthus (L.) Corda CLAGLO: Cladophora glomerata (Linnaeus) Kützing CRAFIL: Cratoneuron filicinum (Hedw.) Spruce RANFLU: Ranunculus fluitans Lam. MYRSPI: Myriophyllum spicatum L. OEDOGONIUM sp: Oedogonium sp. Link OSCILLATORIA sp.(Vaucher 1803) ex Gomont 1892 PELEND: Pellia endiviifolia (Dicks.) Dumort. POTCRIS: Potamogeton crispus L. POTNAT: Potamogeton natans L. POTPEC: Potamogeton pectinatus L.
DERPSPX: Dermatocarpon luridum (With.) J.R. Laundon, RANPEN: Ranunculus penicillatus (Dum.) Bab.

FISCRA: Fissidens crassipes Wilson ex Bruch \& Schimp. PLARIP: Platyhypnidium riparioides (Hedw.) Dixon FONANT: Fontinalis antipyretica Hedw.

FONSQU: Fontinalis squamosa Hedw.

SCAUND: Scapania undulata (L.) Dum. SPAEM: Sparganium emersum Rehm. CINRIP: Cinclidotus riparius (Host ex Brid.) Arn. ELONAT: Elodea nuttallii (Planch.) St John ELOCAn: Elodea canadensis Michaux LEMFLU: Lemanea fluviatilis (Limnaeus) C. Agardh LEMMIN: Lemna minor L. MICROSPORA sp. Thuret SPAERE: Sparganium erectum L. VAUCHERIA sp. Vaucheria spde Candolle ZANPAL:Zannichellia palustris L. LEPRIP: Leptodictyum riparium (Hedw.) Warnst. THAM ALO: Thamnobryum alopecurum (Hedw.) Gangulee 